\title{
The bactericidal activity of quaternary ammonium salts with 2-hydroxyethyl group
}

\begin{abstract}
In this work we have synthesized a small series of novel quaternary ammonium salts with 2- hydroxyl group obtained and studied their bactericidal activity. Recently we reported about the antimicrobial and bactericidal activity of secondary amine with 2-hydroxyethyl group..$^{1,2}$ Simplicity of synthesis of this compound predetermines its application in practice as antimicrobial derivative.
\end{abstract}

Keywords: ethanolamine, quaternary ammonium salts, antimicrobial activity, bactericidal properties, eschericia coli (st. 1257), staphylococcus aureus (st. 906)
Volume 2 Issue 4 - 2018

Torosyan GH, Hovhannisyan NR

National Polytechnic university of Armenia, Armenia

Correspondence: Torosyan GH, National Polytechnic University of Armenia, Doctor of Chemical Sciences, Yerevan, Armenia, Email gagiktorosyan@seua.am

Received: June 28, 2018 | Published: July 12, 2018

\section{Introduction}

The chemical and spatial structure of a substance determines its bioactivity. During is designing the drug the chemists are tried to take into account, introducing the appropriate chemical groupings into the potential drug substance. The presence of alkyl chains, their elongation increases the lipophilicity of drug substances (solubility in fatty tissues that can serve as a drug depot) and facilitates their passage through bio-membranes. The branched alkyl substituents and the presence of halogen atoms make it difficult to metabolize (in particular biooxidation) drugs. The use of drugs with bioactive alcohol group changes the polarity of the drug molecule, improves the manifestation of pharmacological activity.

There are one century as Quaternary ammonium salts (QUAT) are widely used for the control of bacterial growth in clinical and industrial environments, ${ }^{3,4}$ they have also been increasingly deployed in the treatment of bacterial infections. In our group, we have systematically studied chemistry and finding new bactericidal active nitrogen containing organic molecules (amines, amides, quaternary ammonium salts (QUAT). ${ }^{1,2}$ Recently, we have described a series of QUAT with a wide variety of alkyl and 2-hydroxyethyl group, which had been synthesized by this way. ${ }^{1,2}$

$$
\begin{aligned}
& \mathrm{R}_{2} \mathrm{NCH}_{2} \mathrm{CH}_{2} \mathrm{OH}+\mathrm{R} \mathrm{R}^{\prime} \mathrm{Br} \stackrel{\Delta}{\longrightarrow} \mathrm{R}_{2} \mathrm{~N}-\mathrm{R}^{\prime} \\
& \mathrm{R}_{2}=\underline{\mathrm{H}}_{2}(\mathbf{1}) ;\left(\mathrm{CH}_{3}\right)_{2}(\mathbf{2}) ; \mathrm{C}_{2} \mathrm{H}_{5}(\mathbf{3}) \\
& \mathrm{R}^{\prime}=\mathrm{C}_{7} \mathrm{H}_{15}-\mathrm{C}_{9} \mathrm{H}_{19}(\mathbf{2}, \mathbf{3}) ; \mathrm{C}_{10} \mathrm{H}_{21}(\mathbf{4}) ; \mathrm{C}_{12} \mathrm{H}_{25}(\mathbf{5}) ; \mathrm{C}_{16} \mathrm{H}_{33}(\mathbf{6})
\end{aligned}
$$

With the purpose of studying of antimicrobial activity a number of new quaternary ammonium salts (QUAT) containing 2-hydroxyethyl group were synthesized. For obtaining of these salts the ethanolamine were used. The structure of QUAT spectra were recorded by ${ }^{1} \mathrm{H}$ spectra on a Bruker AVANCE 400 spectrometer at operating frequency of 400 and the composition was established by the methods of elementary analysis. Chemical shifts were measured with reference to the residual protons of the solvents DMSO-d,${ }^{1} \mathrm{H}^{1,2}$

The bactericidal properties of QUAT were studied by disinfection of bathy test objects contaminated with a microbial suspension (containing $2 \mathrm{ml}$ microbial bodies in $\mathrm{ml}$ ), in reference strains of Escherichia coli (1257) and Staphylococcus aureus (906), in exposures $5,10,15,20,25,30$ minutes. ${ }^{4}$ Each concentration is tested in at least three replicates.

It has been established that QUAT $\underline{1}$ does not possess bactericidal properties (Table). The introduction of two methyl and two ethyl groups gives for learning substances a high bactericidal activity, which is especially evident in salts $\underline{\mathbf{2}}$ and $\underline{\mathbf{3}}$. It should be noted that a similar pattern is observed when studying inhibitory activity. Previously, it has been established that, this QUAT have a higher inhibitory activity to the corrosion of metals in acidic conditions. ${ }^{2}$ The anti-corrosion activity increases also by the same way, which is give the possibilities

\begin{tabular}{|c|c|c|c|c|}
\hline \multirow{2}{*}{ S.No } & \multirow{2}{*}{ QUAT } & \multirow{2}{*}{$\begin{array}{l}\text { The concentration } \\
\text { QUAT of solution, } \%\end{array}$} & \multicolumn{2}{|c|}{$\begin{array}{l}\text { Exposure in minutes, during which the drug has a } \\
\text { disastrous effect on strains }\end{array}$} \\
\hline & & & $\begin{array}{l}\text { Eschericia coli } \\
\text { (st. 1 257) }\end{array}$ & Staphylococcus aureus (st. 906) \\
\hline 1 & $\begin{array}{c}\mathrm{H}_{2} \stackrel{+}{\mathrm{N}}=\mathrm{CH}_{2} \mathrm{CH}_{2} \mathrm{OH} \\
\underset{\mathrm{Br}}{-}\end{array}$ & 1,0 & Do not kill for $30 \mathrm{~m}$ & Do not kill for $30 \mathrm{~m}$ \\
\hline 2 & 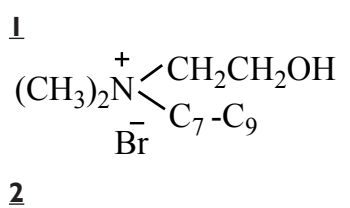 & $\begin{array}{l}1,0 \\
0,5 \\
0,1 \\
0,05\end{array}$ & $\begin{array}{l}5 \\
5 \\
10 \\
15-20\end{array}$ & $\begin{array}{l}5 \\
5 \\
5 \\
10-15\end{array}$ \\
\hline
\end{tabular}
to use that QUAT as bio-anticorrosion materials. ${ }^{5,6}$

Table The bactericidal properties of synthesized QUAT ( $\mu \mathrm{g} / \mathrm{ml})$ 


\begin{tabular}{|c|c|c|c|c|}
\hline S.No & QUAT & $\begin{array}{l}\text { The concentration } \\
\text { QUAT of solution, } \%\end{array}$ & $\begin{array}{l}\text { Exposure in minu } \\
\text { disastrous effect } 0\end{array}$ & $\begin{array}{l}\text { Iring which the drug has a } \\
\text { ins }\end{array}$ \\
\hline 3 & 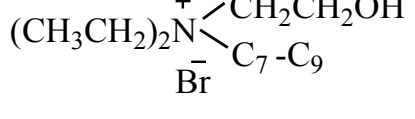 & $\begin{array}{l}1,0 \\
0,5 \\
0,1\end{array}$ & $\begin{array}{l}15 \\
20-25 \\
\text { Do not kill for } 30 \mathrm{~m}\end{array}$ & $\begin{array}{l}10 \\
15-20 \\
\text { Do not kill for } 30\end{array}$ \\
\hline 4 & 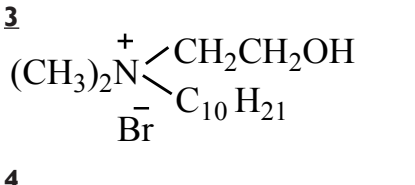 & $\begin{array}{l}1,0 \\
0,5 \\
0,1 \\
0,05\end{array}$ & $\begin{array}{l}5 \\
5 \\
5 \\
10\end{array}$ & $\begin{array}{l}5 \\
5 \\
10 \\
15\end{array}$ \\
\hline 5 & $\underset{5}{\left(\mathrm{CH}_{3}\right)_{2} \mathrm{~N}} \stackrel{+}{-}-\mathrm{CH}_{2} \mathrm{CH}_{2} \mathrm{OH}$ & $\begin{array}{l}1,0 \\
0,5 \\
0,1 \\
0,05\end{array}$ & $\begin{array}{l}5 \\
5 \\
15 \\
15\end{array}$ & $\begin{array}{l}5 \\
5 \\
15 \\
20\end{array}$ \\
\hline 6 & $\begin{array}{c}\left(\mathrm{CH}_{3}\right)_{2} \mathrm{~N} \\
\overline{\mathrm{Br}}\end{array}-\mathrm{CH}_{16} \mathrm{CH}_{33} \mathrm{CH}_{2} \mathrm{OH}$ & $\begin{array}{l}1,0 \\
0,5 \\
0,1 \\
0,05\end{array}$ & $\begin{array}{l}5 \\
5 \\
20 \\
25\end{array}$ & $\begin{array}{l}5 \\
10 \\
25 \\
25\end{array}$ \\
\hline
\end{tabular}

\section{Conclusion}

The results of investigation of antimicrobial activities have shown that these salts reveal bactericidic properties towards standard strains of Eschericia coli (st. 1257) and Staphylococcus aureus (st. 906). The most active are ammonium salts containing decyl radical. Bactericidal activity increases to decyl analogue QUAT $\underline{4}$, then it begins to decrease in all likelihood, peak activity is manifested in the case of the decyl analogue. The comparison of the obtained results confirms the dependence of antibacterial activity from the nature of alkyl groups in the structure of QUAT.

\section{Acknowledgments}

None.

\section{Conflict of interest}

Author declares that there is no conflict of interest.

\section{References}

1. Torosyan GH, Hovhannisyan NR. The antimicrobial and bactericidal activity of secondary amine with 2-hydroxyethyl group. MOJ Bioorganic \& Organic Chemistry. 2018;2(3):142-143.

2. Torosyan GH. The Selective N-Alkylation of Monoethanolamine in PTC Condition. MOJ Bioorganic \& Organic Chemistry. 2018;2(1):19-21.

3. Shtyrlin NV, Sapozhnikov SV, Galiullina AS. Synthesis and Antibacterial Activity of Quaternary Ammonium 4-Deoxypyridoxine Derivatives. BioMed Research International. 2016, 3864193.

4. Minbiole KPC, Jennings MC, Ator LE, et al. From antimicrobial activity to mechanism of resistance: the multifaceted role of simple quaternary ammonium compounds in bacterial eradication. Tetrahedron. 2016;72(25):3559-3566.

5. Torosyan GH. The physiological active compounds. 1987;19:46-48.

6. Labinskaya AS. The Microbiology, Microbiological research technique. Russia: Medicina; 1978. p. 394. 